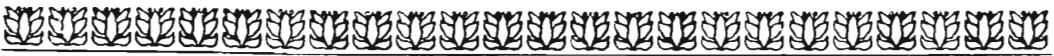

\section{REFORMA DO ENSINO SUPERIOR}

\author{
São Paulo, 10 de Dezembro de 1929. \\ Meus Collegas Redactores da Revista da Faculdade \\ de Direito de S. Paulo.
}

Ao solicitar hoje a inserção do pequeno estudo que lhes envio com esta carta nas columnas da Revistas da Faculdade de Direito de São Paulo, peço licença para adduzir algumas consideraçóes sobre a materia nelle contida. Tracta-se, como sabem, de uma breve representação sobre pontos em que a reforma do ensino superior se impõe como sendo premente. E' um appello que ao Congresso Federal deveria ser apresentado, si, após discussão, fosse approvado pela Congregação dos Professores da Faculdade de Direito de São Paulo. Outros muitos pontos da organização do ensino superior deveriam, julgo eu, ser objecto de modificação, e provavelmente mais desenvolvidos se tornariam os termos do meu trabalho, si houvesse sido debatido pelos Professores. Succedeu porém que, pelo inicio dos exames, exigindo alhures a presença dos membros da Congregação, $e$ pela approximação do encerramento do Congresso Federal, foi frustrado o meu plano, tornando-se impossivel, e, quando possivel, inefficaz qualquer discussão, bem como a remessa da representação em tempo util para ser conhecida pelo Poder Legislativo. Fazem os professores o que podem para darem a seus discipulos os conhecimentos mais proveitosos aos bachareis em Direito, mas infelizmente não os auxilia 
a nossa organização do ensino superior, que não corresponde aos progressos da Didactica. Julgo será de vantagem, para serem firmadas ideas quanto aos estudos universitarios que tanto têm, nestes ultimos tempos, occupado a attenção publica, serem conhecidas dos "leitores da Revista as suggestões que apresento á critica dos doutos neste ramo da instrucção publica, um dos mais interessantes na Didactica.

Peço permissão para fazer sentir que muita coisa ainda eu proporia, si não temesse ser malsinado, como fui por um illustre Professor da Faculdade de Pernambuco, de propugnador de ideas subversivas acerca do ensino juridico. Os norteamericanos têm suas universidades fluctuantes, $e$ creio inutil encarecer quanto seriam proveitosas para nós, afim de que os estudantes soubessem o que vae pelo mundo, e não incidissem no erro de que nos dá idea o poeta, quando escreveu:

"Et pense, à son enclos, bornant son horizon, Que le monde finit où finit sa maison."

Abolimos, em má hora, o estudo da Legislação Comparada, e verdadeira heresia seria pois no Brasil minha indicação de estabelecimento de universidades á feição das que acabo de mencionar Julgar-me-iam um homem paradoxal. O escopo que se têm proposto nossos dirigentes é o da formação de advogados aresteiros: nada mais. A America do Norte tem as denominadas "travel organizations", destinadas a facilitarem as peregrinações dos estudiosos pelo estrangeiro, mas os nossos rapazes não podem pretender tal jornada circulatoria, porque nenhuma facilidade lhes é concedida pelo nosso Governo. Nem mesmo lhes é possivel a frequencia das Faculdades estrangeiras, porque o tempo do curso nellas coincide com o em que são feitos estudos neste hemispherio, onde os trabahos academicos deveriam ser effectuados nos mezes em que se dão as férias. 
Tendo, a pedido da Fundação Carnegie, ido cursar as aulas da Academia de Haya, dois intelligentes moços de nossa Faculdade, encontraram obices para os exames aqui, em vista de terem sido forçados, por força da lei que rege o ensino superior, a perderem o anno em São Paulo! ! ! Perderam o anno porque fizeram estudos extraordinarios, proveitosissimos!!!. Na China antiga, não havia cursos superiores, $e$, por este motivo, aquelle prudente povo facilitava a ida á Europa de milhares de rapazes, tendo sido precisamente esta infiltração de ideas novas no Celeste Imperio, esta disseminação pelos novos chinezes de doutrinas modernas determinadoras da transformação de que temos sido testemunhas nós que vivemos neste seculo de vertiginosas alterações. E' muito louvavel certa prudencia na adopção de novos institutos e no abandono dos que se mostram inconvenientes para a sociedade em que ignoram, mas o Brasil parece ter levado muito longe seu espirito conservador. Cumpre não rejeitar as innovações que têm noutros paizes dado bons resultados. Ha meio seculo, quando eu me sentava nos toscos bancos destinados aos alumnos da Faculdade de Direito, echoava pelas arcadas o lemma, então na ultima moda: "Le monde marche" Hoje não mais se repete isto sinão fóra da Faculdade em relação aos prazeres novos creados pela imaginação dos emprezarios de cinemas, cabarets etc. Nos logares de diversões, sim, repercute a phrase: "Como estamos adeantados!" De progresso em sciencias, letras e artes, poucos cogitam.

Seu collega e ven. att. ${ }^{\circ}$

Jỗo ARRuda. 